\title{
The Disraeli Family and the History of the Jews
}

\author{
MARTIN GOODMAN \\ UNIVERSITY OF OXFORD, UK
}

\begin{abstract}
One of the illustrated Victorian editions of Whiston's translation of Josephus, printed in London in 1848 , contains 'a Sequel to the History of the Jews; continued to the present time'. The title page gives no indication of the origins of this Sequel, which comprises a substantial history of the Jews from the first century $\mathrm{CE}$ to the nineteenth century. The article discusses the reasons to suppose that the Sequel was composed by the literary historian Isaac D'Israeli and completed rapidly after his death by his children, Benjamin Disraeli and his sister Sarah. The composition and publication history of the Sequel shed light both on the Jewish identity of Isaac and on the complex attitude of Benjamin to the public debates on Jewish emancipation, in which he intervened dramatically for the first time in December 1847.
\end{abstract}

On the bookshelves of many pious homes in the United Kingdom and the United States in the nineteenth century a copy of William Whiston's translation of the works of the first-century Jewish writer Josephus was to be found alongside the family bible, often with similar ornate binding and extensive illustration. Whiston, who had succeeded Isaac Newton as Lucasian Professor of Mathematics in Cambridge, first published his translation in 1737, but it was in the following century that his version of Josephus's histories became a publishing phenomenon, with numerous editions produced at many different presses in Scotland, Ireland, and the United States. The Whiston version is what Thomas Hardy will have had in mind when he referred in passing in 1886 to the folio of Josephus on the dining room table of the mayor of Casterbridge, and the 'book called 'Josephus', an old leatherbound volume, smelling of a hundred voyages, very solid and very like the Bible, but enlivened with accounts of battles and sieges', which Rudyard Kipling portrayed as suitable reading for American fishermen in Captains Courageous, published in 1897, would also have been a copy of Whiston's translation. ${ }^{1}$

One of the most magnificently illustrated of these editions of Whiston's Josephus, printed in c.1876 in New York by the London Print and Publishing Company, contains 'a

\footnotetext{
${ }^{1}$ M. Goodman, Josephus's The Jewish War: a biography (Princeton University Press, 2019), pp. 86-7.
} 
sequel to the History of the Jews; continued to the present time'. ${ }^{2}$ The title page gives no indication of the origins of this Sequel, a substantial history of the Jews from the first century $\mathrm{CE}$ to the nineteenth century which runs to 227 large pages of small type, but (apart from the three pages at the end which cover the period from 1848 to 1876) it can be traced back to an earlier edition of Whiston printed in London in 1848, probably by John and Frederick Tallis, who specialised in the production of maps and atlases. ${ }^{3}$ There are reasons to suppose that the original 1848 version was composed by the literary historian Isaac D'Israeli and completed after his death by his children, Benjamin Disraeli and his sister Sarah. The composition and publication history of the Sequel shed light both on the Jewish identity of Isaac and on the complex attitude of Benjamin to the public debates on Jewish emancipation in which he intervened briefly but dramatically for the first time in December 1847, just before his father died in January 1848, only to distance himself from the cause for the remainder of his political career.

The Sequel constitutes a roughly continuous narrative of Jewish history from the destruction of the Jerusalem Temple in 70 CE down to the mid nineteenth century. It is divided into six 'books' of unequal lengths. The first book's title announces it as 'comprehending the events of two centuries, from the fall of Jerusalem to the time of the emperor Severus'. The second book 'comprehends events of the third, fourth and fifth centuries, to the time of Mohamet'. The third book, which is the shortest, deals with 'events from the sixth to the ninth century, and to the first appearance of the Jews in England'. The fourth book goes 'from the ninth century to the reign of King Edward the first of England'. The fifth book covers the period 'from the thirteenth century to the time of Oliver Cromwell'. The final book, at 63 pages the longest by some way, deals with 'events affecting the Jews from the middle of the seventeenth century to the present time'. The history is thus heavily weighted towards recent times.

\footnotetext{
${ }^{2}$ The complete Works of Flavius Josephus comprising the History of the Jews, 8c., and the Life of Josephus, written by himself. Translated by William Whiston, Professor of Mathematics in the University of Cambridge. With a Geographical Summary of the Land of Promise, Illustrated with Coloured Maps. And a Sequel to the History of the Jews, continued to the present time. (London and New York: The London Printing and Publishing Company, n.d.).

${ }^{3}$ The Complete works of the learned and authentic Jewish historian, Flavius Josephus: comprising the Antiquities of the Jews, a History of the Jewish Wars, three dissertations concerning Jesus Christ, John the Baptist, etc., and the Life of Josephus, written by himself. Translated by William Whiston, Professor of Mathematics in the University of Cambridge. With a Sequel to the History of the Jews: continued to the present time. Reprinted Attic Books, 2008. The original title page of the volume does not state the publisher, but the front matter of the 2008 reprinted edition states 'Original printing done by the J. \& F. Tallis Company'. A different edition of the identical material by J.G. Murdoch, also undated, must be a reprint rather than the original printing, since J.G. Murdoch was set up as an independent publisher only in 1871.
} 
The first two books tell the reader as much about general Roman history and the rise of Christianity as about the history of the Jews: accounts of the rabbinic sages of the Mishnah and Talmud are somewhat simplistic and interspersed with general observations on characteristics of Judaism, such as the Cabala (647-8), for which the evidence in fact derives from later periods. The reader has a sense of a historian not wholly in control of his material: the author notes in a section on Jews in the fourth and fifth centuries that 'the various scenes connected with Jewish history cannot be given in exact chronological order' (714), and an excursus on the Samaritans is explicitly introduced as 'a retrospective glance' which 'may be allowed to interrupt our narrative' (720).

Nonetheless, the narrative quite impressively covers all parts of the Jewish world, including sporadic descriptions of exotic Jewish communities in far-flung places such as China and India, despite an explicit emphasis on Jewish life in England since the early Middle Ages. Striking is the dedication of the final book to an account of 'the various efforts made in the course of the present century to relieve the Jews of England from the remains of that oppression and proscription which their ancestors had for centuries to deplore' (827) and the detailed relation of parliamentary proceedings in favour of Jewish emancipation both in 1753 (820-826) and, in the final pages, from 1829 to the present. The culmination of the story of emancipation is portrayed in ecstatic terms, with the author remarking that, although 'in former chapters we have had to detail acts of heartless oppression and deeds of murderous violence', now 'a more grateful task remains to be performed, and a story of truth winds up with the joy and triumph ordinarily reserved for the denouement of a romance' (864).

The cause of the joy is made explicit in the last page of the Sequel (885), which records the vote of the House of Commons in February 1848 in favour of a bill for emancipation and the failure of the High Sheriff in Chelmsford to summon up support at a public meeting on 24 February 1848 'to petition the legislation against the bill'. The final paragraph of the volume states that 'the decisive vote of the Commons of England put an end to all doubt as to their future situation here'. This triumphal conclusion provides a rather precise date for the publication of the Sequel, since the book must have gone to press after 24 February but before the middle of May 1848, when the decision of the House of Commons was blocked by the House of Lords. 
The celebratory conclusion of the Sequel contrasts to the frequent reference to persecution in much of the rest of the narrative, but the tone is kept from being lugubrious by a lightness of touch, a multiplicity of anecdotes, and frequent sceptical asides about the foolishness of religion. Most mockery is reserved for rabbinic Judaism, with (for instance) an echo of Basnage's exclamation 'Que de bagatelles' in regard to a story from the Talmud (657), but some aspects of Christianity, such as the miracle of the true cross witnessed by the empress Helena (669-70) and the self-mortification of St Dominic (761), are treated with similar sardonic humour. The author seems to assume a general English readership, educated enough not to need a history of the Crusades (744), for whom reference to Christ as "our Saviour" $(662,675,719)$ or 'the true Saviour of mankind' (639) would come naturally. The narrator does not withhold strong opinions, expressing surprise that, in the time of Oliver Cromwell, Williams Prynne was 'one of the fiercest adversaries the Jews had to encounter' (819), disdain at the 'equivocating' and 'pusillanimous' statesmanship of Lord Chatham in a speech in Parliament in 1753 (825), and esteem both for Mahomet, 'one of the most remarkable of mankind' (718), and for some of the leading Jews of his own day, such as Moses Mendelsohn (827-8) and Moses Montefiore (851, 862).

Much of the narrative is stitched together from citations or paraphrases of a large array of sources, often general histories from which material relating to Jews has been excerpted. These sources are cited sometimes by title (itself often much abbreviated or paraphrased), sometimes by author, and occasionally anonymously. For antiquity, extensive use is made of Capefigue, Gibbon and Mosheim; for the Middle Ages, the author cites at length Bussey and De Mariana. Among older works specifically about Jews, the author used especially Basnage, Blunt, Milman and Tovey. Many of the works cited were quite recent. Those published since 1840 included G. Aguilar, The Spirit of Judaism (1842); A.A. Bonar and R.M. M'Cheyne, Narrative of a mission of inquiry to the Jews from the Church of Scotland in 1839 (1842); G.M. Bussey and T. Gaspey, The Pictorial History of France and the French People, to the Revolution (1843); D.A. De Sola and M.J. Raphall, Eighteen treatises from the Mishna (1843); J. Francis, History of the Bank of England: its times and traditions (1847); T. Gaspey, The Life and Times of the good lord Cobham (1844); the preface by L. Loewe to I.B. Levinsohn, Efes Damim (1841); M.A. Lower, The Curiosities of Heraldry (1845); W. Thornborrow, Advocacy of Jewish Freedom (1847); F.G. Tomlins, A Universal History of the Nations of Antiquity (1844); J. Wolff, Narrative of a mission to Bokhara in the years 1843-1845 (1845); and an anonymous pamphlet entitled Progress of 
Jewish_Emancipation since 1829, published in London in 1848. The Sequel also quotes at length from a travel journal from 1838-1839 of Judith Lady Montefiore which, it is stated, 'has never been published. It is deeply interesting, from the pure spirit of love and devotion which breathes in every page, but can only be quoted here where it throws light on the state of the modern Jews, or brings before us Scripture scenes such as they now exist' (852).

Among the authors most often cited is Isaac D' Israeli. The first book is rounded off (662) with a paragraph marvelling at the survival of Jews in the face of persecution over many centuries and ends by asserting that 'the fact is so wonderful that, with the proof before our eyes, we almost doubt, and cannot but adopt the striking reflections of Mr. D'Israeli on the subject'. The rhetorical passage which then follows is excerpted from D'Israeli's The Genius of Judaism (1833), although the reader is not told this. An account of the Talmud on pages 664-665 is taken (without mention of the name of D'Israeli) from the Curiosities of Literature, D'Israeli's most popular work, which had originally been published in 1791 and was frequently reissued down to the 1840s. A discussion of polytheist contempt for the Jewish Sabbath (695-6) is illustrated by two quotations from The Genius of Judaism, introduced by “in the language of D'Israeli”. A sceptical discussion of the talmudic rationale for deeming that sacred books defile the hands is attributed to 'the author of 'Curiosities of Literature' (703). A paragraph attacking the 'extravagant conclusions' and 'oriental imaginations of the Rabbins' is attributed to 'the author of 'The Genius of Judaism'” (714). Another passage from The Genius of Judaism (244-5), about the settlement of Spanish and Portuguese Jews in England is accurately reproduced and attributed in the Sequel but it inserted inappropriately into an account of the history of English Jews in the time of Henry I (739).

What are the reasons to suppose that the Sequel into which these citations were inserted was itself composed by Isaac D'Israeli? During the 1840s, when (in light of the works cited) much of the Sequel must have been written, Isaac D'Israeli was living in the Buckinghamshire countryside in Bradenham House, where he had moved in 1829. ${ }^{4}$ He was a prolific writer, and between 1790 and 1840 he generally had a book in the press. A freethinker, he was accused as early as 1794 for being 'Gibbonian' in his 'sneering infidelity'. ${ }^{5}$ Most of his writings were on literary subjects, but in the early 1830 s he achieved

\footnotetext{
${ }^{4}$ J. Ogden, Isaac D'Israeli (Oxford: Oxford University Press, 1969), p. 155.

${ }^{5}$ Ogden, Isaac D'Israeli, p. 194.
} 
a temporary reputation as a historian through his history of the reign of Charles I, for which he was awarded an honorary degree by the University of Oxford in $1832 .{ }^{6}$ By 1840 he had lost much of his sight and he was heavily dependent on his daughter Sarah for help with reading and writing. ${ }^{7}$

Isaac's relationship to his Jewish origins was complex. He had resigned from Bevis Marks synagogue in 1817 and a reviewer was able to remark in 1823, apparently without irony, that it was not universally known that he was 'by birth a member of the Hebrew nation, ${ }^{8}$ but he never disguised his Jewishness and at intervals in his literary career he wrote on various Jewish subjects, producing not only The Genius of Judaism (1833) but also articles on Moses Mendelsohn in 1798 and on the Paris Sanhedrin in 1807. ${ }^{9}$ Nonetheless, when writing about Jews, he usually used the third person (Ogden 194), as if he was himself a Christian. ${ }^{10}$ His ambivalence is illustrated by his initial strong determination that The Genius of Judaism be published anonymously; he agreed to add his name to the title page for the second edition only on the insistence of his publisher that this could increase his sales. ${ }^{11}$

Isaac's interest in Jews is reflected in his papers, some of which are included in the archive of his son Benjamin which was preserved in Hughenden Manor and are now housed in the Bodleian Library. ${ }^{12}$ These papers include a small, leather-bound notebook (G II 39 (258/1)) with numbered pages, which contains much material on Jewish history in Isaac's hand, with references to many of the books cited in the Sequel, including De Marianna, Tovey, Stowe, Prynne and especially Basnage. ${ }^{13}$ When these passages were excerpted is unclear, and it is possible that they related (if obliquely) to the composition of The Genius of Judaism in $1833 .{ }^{14}$ But unrelated to anything published in his previous works is the material found in a large notebook, with marbled cover and 'Curiosities of Literature' embossed on the spine, in which most pages are blank and none of the pages are numbered (G II 12 (254)).

\footnotetext{
${ }^{6}$ Ogden, Isaac D'Israeli, p. 160.

${ }^{7}$ Ogden, Isaac D’Israeli, pp. 174, 189.

${ }^{8}$ Ogden, Isaac D'Israeli, p. 194.

${ }^{9}$ M. Spevack, 'D'Israeli \& Disraeli and the Genius of Judaism', Ashkenas-Zeitschrift für Geschichte und Kultur der Juden 12 (2005), p. 135. Identification of Isaac as author of the anonymous article on Mendelsohn in The Monthly Magazine 6 (1798), pp. 38-44, is plausible but not certain.

${ }^{10}$ Ogden, Isaac D'Israeli, p. 194.

${ }^{11}$ Spevack, 'D'Israeli \& Disraeli', p. 139.

${ }^{12}$ Hughenden Papers are quoted with the kind permission of the Bodleian Library, University of Oxford, and the National Trust for Places of Historical Interest and Natural Beauty.

${ }^{13}$ M. Spevack, 'In the shadow of the son: Isaac D'Israeli and Benjamin Disraeli', Jewish Culture and History 8 (2006), p. 87 , notes that Basnage was of Isaac's favourite authors.

${ }^{14}$ Spevack, 'D'Israeli \& Disraeli', p. 141.
} 
A torn page inserted at the end of the book includes 'Books to consult' on the history of Jews, noting about 'J. Jackson - theological works' that it 'has not the candour and caution of Basnage'. The notebook itself has a series of jottings about Jewish history, especially persecutions, citing Abendana, Addison, and Prynne, among others, and notes about other authors to be consulted.

Most significant for the current investigation is what appears to have been a rough first draft of a preface for a history of the Jews. The handwriting is very scrappy, with frequent deletions and interlinear insertion, but it is worth citing the text at some length where it is legible (with square brackets and ' $\mathrm{D}$ ' to indicate material which Isaac crossed out, square brackets and ' $A$ ' to indicate words which he added above the line without marking how they fit in to the main text, and ellipses to indicate material omitted because it is too hard to read):

I am confident that throughout this History although my name indicates a Jewish origin, no traces of the Judaic Genius, will be discovered in [D: the] it's pages. No [D: apologies] palliations of Superstitions; no apologies for radical [D: crimes] offences; no partialities for [D: a sacred] that divine favour [D: of] which many [D: this people] still foolishly [D: deceive themselves] dream. The ... imagination of visionaries; the rhapsodies of diseased minds; the tasteless romances of Rabbins.

On the contrary, the Jews (although they ... [A: I fear] not to be interested by the declarations of the philosophic writer) shall have no reason to complain of my being inimical to their [D: prosperity] cause, negligent of their Interest, or ... those adamantine truths which shall resist their bigotted enemies [D: which] while ... Humanity...

[D: I will spare no]

My feeble talents shall exert their last energies; I shall rejoice to brand oppression with its enormous guilt; to [D: detect] expose those inhuman Laws which [even] the European legislation [, even of all Europe] have by a singular and popular error, been induced to decree; Laws which have made this unfortunate nation resemble the Helotes 
among the [Spart] Lacedaemonians. [D: I shall] Often shall I have occasion to contemplate these unhappy [D: vagrants, fixed] wanderers ... on the tortures of inquisitorial Cruelty; [D: and] or what is still worse ... to that [D: contempt with] Hatred which has hardly left, [D: enlightened Europe] and with that Contempt which still [D: lies] remains in enlightened Europe. If I have Occasion often to indulge Railery, I must sometimes join my Lamentation; for he who writes the history of the J.N. and with progress of his labours, [[D: writes] drops not on his papers a silent tear, or does not give way, to the [D: excoriation] indignity which swells in his heart, [D: must be unworthy] can have no claims to Genius, no sensibility to paint the scenes that glow on the Fancy, no [D: judgement] ... to express those reflections which arise from Truth.

The history to which Isaac referred in the first line of this preface looks very like the history to be found in the Sequel, and, in view of his reference to the 'last energies' he will exert and the feebleness of his handwriting, it is most likely that these words were composed in the 1840 s as he was losing his sight in his old age. ${ }^{15}$

Isaac certainly had both the erudition and the resources to write a history with the ambitious scope of the narrative in the Sequel. Many of the general books required for the history will have been available to him in his renowned library in Bradenham, and, as a devoted bibliophile, he would have expected to acquire any necessary volumes he lacked. Most of the library was sold in March 1849, but the catalogue for the sale at Sotheby's, which is preserved in the Hughenden archive and specified well over 10,000 volumes (G/VI/6), includes almost none of the books on Jews to which he referred in the notebooks or his publications, presumably because they were not expected to appeal to the antiquarian book collectors who attended the sale. Some of the books on Jews kept by his son Benjamin featured in a later sale, held at Sotheby's in October 1881 after Benjamin's death. ${ }^{16}$ A few are

\footnotetext{
${ }^{15}$ Spevack, 'D'Israeli \& Disraeli', p. 148, noted that this text looks like a preface but suggested that it might have been a draft preface of The Genius of Judaism, even though he remarked (at n. 51) that 'interestingly, in a note D'Israeli refers to the work as 'this History', The reference is not in a note but in the first line of the Preface. In any case, D'Israeli stated explicitly on page 239 of The Genius of Judaism that 'I am not writing the history of the Jews, for antiquaries, but the Genius of Judaism for philosophers', giving this as a reason to pass over in silence the evidence that there were Jews in England during the reigns of Elizabeth, James and Charles I.

16 T. Endelman, Broadening Jewish History: towards a social history of ordinary Jews (Oxford and Portland, Or.: Littman Library 2011), p. 204.
} 
still in the library in Hughenden, where the volumes of the 1716 edition of Jacques Basnage, L'Histoire et la religion des Juifs, have been marked up in pencil, particularly in volumes 1, $2,4,5$ and 6 , with lists on the inside back covers of the page numbers of relevant passages. ${ }^{17}$

But, although the draft preface and the tone and content of the Sequel point to Isaac as author, the origins of the Sequel cannot be ascribed only to him, since he died on 19 January 1848 , just over a month before the meeting at Chelmsford to which the Sequel refers on its last page. Someone else must have seen the history through its final publication. Who did this, and why did they elect to publish the history anonymously as an addendum to Whiston's Josephus?

Part of the answer lies in the evidence that whoever made the final preparations for the press worked at speed, since the volume contains many printing mistakes. So, for instance, something went awry with the numbering of the six books: the second book is printed as a second 'Book I' (663), the fourth book as a second 'Book III' (779), the fifth book as 'Book IV' (785) and the sixth book as 'Book V' (812). That these were simple errors is clear, because they were corrected in the second edition of the Sequel, published in c. 1876.

The most egregious errors in the Sequel are to be found in the last forty pages, including the material which must have been added after Isaac's death. The resumption of parliamentary debate on the Jewish emancipation bill on 17 December 1847 is said to have taken place on 7 December (872). The meeting of the House of Commons on Friday 11 February 1848 is specifically dated 'on Friday, the $12^{\text {th }}$ February' (879). Sir Moses Montefiore, whose name 'Moses' is extravagantly celebrated on p. 862 after his success in the Damascus affair, is called 'Sir Solomon Montefiore' when first mentioned (849). The 'Index to Sequel' at the end of the volume (890) is extraordinarily brief, with only 28 entries, and it is bizarre in its random choice of subjects, which include Christianity, Constantine, Labarum, Mahomet, Manes, and 'Thornborrow, Mr W. exerts himself to get a Jew elected sheriff of London'; it also gives the wrong page number (644 instead of 647) for the entry on 'Cabala'.

\footnotetext{
${ }^{17}$ Isaac's writing was very cramped, and it is probable that the error on p. 808 of the Sequel, where the title of a book by Giulio Morosini (Derek Emunah, published in 1683) is given incorrectly as 'Dezek Emunah', reflects this poor handwriting. At any rate, whoever made the error must have done so through copying the title in its transliterated form, since the letters resh and zayin in the original Hebrew title are too different to be mistaken.
} 
Part of the hasty editing of the text of the Sequel seems to have been a systematic obfuscation of the considerable extent to which the text contains references to, and citations from, the writings of Isaac D'Israeli. Most striking is the error at the bottom of page 775, which reads (with reference to a story about King Louis of France, who was canonised): 'St. Louis, remarks 'D'Israeli, inferred that the doughty knight did wrong to confute the Jew'. The sentence, which refers to a passage found on p. 185 of The Genius of Judaism, makes no sense. It was corrected in the 1876 edition (713), to read: 'St. Louis," remarks D' Israeli, 'inferred...',

It is not hard to guess who was responsible for this hasty publication, since Sarah had been her father's amanuensis for the past eight years and Isaac's will bequeathed to his son Benjamin a large part of his property, naming him as sole executor. ${ }^{18}$ That this involved for Benjamin the protection of his father's literary legacy is clear from the publication of a new edition of Isaac's best-known work a year after his death, with a long and affectionate memoir of his father by Benjamin dated to 'Christmas, 1848'. ${ }^{19}$ Benjamin and Sarah must have had this project in mind within weeks of their father's demise, since already on 10 May 1848 Benjamin informed his sister in a letter that he had sewn up the agreement with the publisher and that the volume would come out at the beginning of October. ${ }^{20}$

Sarah may well have been the driving force behind the decision to publish Isaac's history anonymously. As Isaac's literary assistant, she was best placed to know the state of the manuscript. Her role as her father's amanuensis was explicitly acknowledged in the long, detailed and encomiastic Times obituary of Isaac, which was printed on 21 January 1848, just two days after his death. In view of the speed of the production of this obituary, it is reasonable to suppose that it may well have been composed by Benjamin, or at least with his aid; it is striking that the first paragraph is devoted to a celebration of Benjamin's literary achievements alongside those of his father. At any rate, the assertion in the obituary that, although Sarah had enabled Isaac to produce Amenities of Literature in 1841 and a revision of his history of the reign of Charles I, he had written nothing since that date despite a project to write a life of Pope, evidently followed the family line; Benjamin added in his memoir later in

\footnotetext{
${ }^{18}$ Ogden, Isaac D'Israeli, p. 189.

${ }^{19}$ B. Disraeli, 'On the life and writings of Mr D'Israeli', in Isaac D'Israeli, Curiosities of Literature, $14^{\text {th }}$ edn., 3 vols. (London: Moxon, 1849), vol. 1, pp. vii-xxxvii.

${ }^{20}$ J.A.W. Gunn and M.G. Wiebe, eds., Benjamin Disraeli Letters, 10 vols. (Toronto, Buffalo and London: University of Toronto Press), no. 1644.
} 
the year only a claim that Isaac had wanted to devote himself to a history of the English Freethinkers. ${ }^{21}$ The Times obituary failed even to mention that Isaac had been born a Jew, and it was perhaps as a riposte to this omission that William Cooke Taylor composed the next month an appreciation of Isaac as a writer on Judaism. The article was sent to Benjamin in advance of publication in the March issue of Bentley's Miscellanies, and Benjamin expressed his general approval of its contents on 23 February 1848. Taylor himself seems to have known only little about his topic, and the appreciation was based mostly on a rather cursory trawl through Isaac's The Genius of Judaism, 'a work of singular merit which has fallen into unaccountable neglect' (p. 222). Taylor noted (p. 223) that 'it is certain that Isaac D'Israeli, though his parents [sic] had quitted the Jewish community, took a lively interest in the question of Jewish emancipation; but, save in the "Portraiture of Judaism" [i.e The Genius of Judaism], we are not aware of his having written directly on the subject'. Evidently, Taylor knew nothing about Isaac's work on Jewish history in the last years of his life. ${ }^{22}$

Benjamin noted in his memoir that his father "was wont to say that the monument to an author was a good edition of his works', ${ }^{23}$ but he and Sarah may have deemed that the history of the Jews would not enhance Isaac's reputation. On the other hand, leaving the unfinished history unpublished would be a betrayal of both Isaac's efforts and Sarah's; the amount of work involved in acting for so many years as secretary to her father, who must have been even more dependent on her after her mother's death the previous summer, should not be underestimated. ${ }^{24}$ Hence perhaps the decision to publish the work anonymously. It may have helped both that anonymous or pseudonymous publication was not unusual in literary circles in England in this period and that this would not be the first time that Benjamin and Sarah had published anonymously a jointly authored work. Their joint novel, entitled $A$ Year at Hartlebury or The Election, which was printed by Saunders and Otley in 1834, remained anonymous until the identity of its authors was unearthed in the late 1970s. As John P. Matthews notes, the impetus to the collaboration was personal and domestic following the tragic death of Sarah's fiancé William Meredith in 1831 and much of the impetus which led to its successful completion came from Sarah rather than her brother. ${ }^{25}$

\footnotetext{
${ }^{21}$ Disraeli, 'On the life and writings', p. xxxv.

${ }^{22}$ W.C. Taylor, 'The late Isaac D'Israeli, Esq., and the Genius of Judaism', Bentley's Miscellanies 23 (1848), pp. 219-25;

Benjamin's letter can be found in Gunn and Wiebe, Benjamin Disraeli Letters, no. 1631.

${ }^{23}$ Disraeli, 'On the life and writings', p. xxxv.

${ }^{24}$ Ogden, Isaac D'Israeli, p. 189.

${ }^{25}$ B. and S. Disraeli, A Year at Hartlebury or The Election, reprinted with appendixes by Ellen Henderson and John P. Matthews (Toronto: University of Toronto Press, 1983), pp. 202-10.
} 
The decision to approach T. and F. Tallis and to seek publication in the Tallis edition of Whiston's Josephus may have been simply opportunistic, since the accurate reproduction of Whiston's text and the inclusion of illustrations in the first part of the volume suggests that preparation of the edition was already well advanced. There is no evidence that either Isaac or Benjamin had any previous dealings with either Tallis brother, but their publishing enterprise was flourishing and the prospect of payment would have been attractive since Benjamin was, even more than usual, short of money, not least as a result of the agreement in March 1847 to purchase Hughenden Manor. ${ }^{26}$ Benjamin pressed ahead at speed in the course of February and March with the winding up of his father's estate. ${ }^{27}$ Isaac's relations with his regular publisher, Edward Moxon, had been tetchy in recent years, and it is unlikely that Moxon would have paid good money to take on the history as a separate volume. The choice of the Whiston edition by T. and F. Tallis may have been helped by precedents in the publication of sequels to Josephus both in French by Basnage and in English by Thomas Taylor (1708), George Henry Maynard (1785) and Thomas Bradshaw (1792), although this was to be the first such sequel to be published anonymously. ${ }^{28}$

It seems likely that much of the work in putting the book through the press in late February and March 1848 was done by Sarah, since by that time Benjamin, who had stayed in Bradenham in mourning for the second half of January, was once again deeply immersed in the complexities of political life both in London and on the continent, where revolutions broke out across Europe in the course of the spring. By contrast, Sarah was left to manage the domestic residue of Isaac's life in the empty house in Bradenham, settling bills from tradesmen according to a letter sent to her by Benjamin on $20 \mathrm{March}^{29}$ As in the composition of $A$ Year in Hartlebury in 1833, the literary project may have served as therapy in mourning.

If this analysis of the origins of the anonymous Sequel is correct, it has implications for understanding Isaac D'Israeli as well as his children. It would appear that Isaac did not abandon his literary work during his final years in Bradenham, as often claimed, ${ }^{30}$ despite the

\footnotetext{
${ }^{26}$ J.P. Parry, Benjamin Disraeli (Oxford: Oxford University Press, 2007), p. 49.

${ }^{27}$ Gunn and Wiebe, Benjamin Disraeli's Letters, no. 1623.

${ }^{28}$ O. Murray, 'The western futures of ancient history', in A. Lianeri (ed), Knowing Future Time In and Through Greek Historiography (Berlin: De Gruyter, 2016), 385-400.

${ }^{29}$ Gunn and Wiebe, Benjamin Disraeli Letters, no. 1639.

${ }^{30}$ Ogden, Isaac D'Israeli, p. 189.
} 
'paralysis of the optic nerve' by which he was handicapped from $1839,{ }^{31}$ but that in old age he became increasingly interested in his Jewish identity, with a particular fascination for the history of the persecution of Jews in different countries and the struggle for Jewish emancipation. These topics had not featured greatly in his earlier writings. ${ }^{32}$ Ogden notes that he was unable to discover any evidence that either D'Israeli or his family were involved in the movement to establish a Reform Synagogue in London during the years that Isaac was living in retirement in Bradenham and therefore implies doubt about the tradition that at the age of 76 , troubled by blindness and gout, Isaac made the journey to London to attend the consecration of the first Reform Synagogue in Burton Crescent. ${ }^{33}$ Lucien Wolf, who seems to have been the first to transmit this story in print, in the preface (xvi) of the centenary edition of Benjamin D'Israeli's Vivian Grey, published in 1904, noted explicitly some ten pages earlier (vii - viii) that 'in preparing the biographical introduction the editor has had the advantage of working throughout with new sources', but Wolf had a fondness for stories such as these, and it is impossible to know whether the story was true. Even if it was true, Isaac would not have joined the new synagogue, because he did not see any value in religion, but, as Wolf noted (xvi), he would have identified with 'those of his relatives and friends' who had set up the new congregation in a civilised, English style.

How much of Isaac's increased interest during the 1840s in Jews and Jewish emancipation was transmitted to his son Benjamin? It has been argued that the close relationship of Benjamin to his father revolved to a large extent around their shared literary interests and that the nearly simultaneous publication of Isaac's The Genius of Judaism and Benjamin's Jewish romance The Wondrous Tale of Alroy was not accidental, ${ }^{34}$ but, although Benjamin never denied his Jewish origins any more than his father, this had no bearing during the 1830s on his public political stance on Jewish emancipation: in 1833 he had encouraged Isaac in the publication of The Genius of Judaism, but this was only in the expectation that the book would sell well while Jewish disabilities were being discussed in parliament. ${ }^{35} \mathrm{He}$ had voted against emancipation in 1837 and he had played no part in the debate in 1841 on a bill to enable Jews to hold municipal office or in 1845, when his own party sponsored another emancipation bill in the House of Commons, ${ }^{36}$ confining any sentiments he wished to express

\footnotetext{
${ }^{31}$ Ogden, Isaac D'Israeli, p. 174.

${ }^{32}$ Ogden, Isaac D'Israeli, p. 202.

${ }^{33}$ Ogden, Isaac D'Israeli, p. 206.

${ }^{34}$ M. Spevack, 'In the shadow of the son', pp. 86-7.

${ }^{35}$ Spevack, 'D’Israeli \& Disraeli', p. 138.

${ }^{36}$ Endelman, Broadening, p. 210.
} 
in favour of Jewish emancipation to the pages of his novels, such as those ascribed to Sidonia in Coningsby, which he had begun writing in September 1843 and which was published in 1844. ${ }^{37}$ This attitude had changed by December 1847. Benjamin might, of course, simply have come to believe in the justice of the Jewish cause, but in light of this new evidence of Isaac's preoccupation with this subject in his last years, it seems likely that the shift was linked to his father's influence.

By 1847 Benjamin was a major figure in the Protectionist wing of the Tory party. He was acutely aware of the ambivalence of his political allies about his Jewish origins. Since 1839 he had begun to mix socially with wealthy Jews such as the Montefiores and Rothschilds, ${ }^{38}$ but his decision to deliver on 16 December 1847 the speech, recorded verbatim in the Sequel (870-871), in which (according to the admiring author of the Sequel) he advocated the admission of Jews to the enjoyment of the rights of Englishmen 'with great effect', was a major political risk. The grounds cited by Benjamin for his advocacy of emancipation, that 'all the early Christians were Jews', went down badly in the House of Commons and almost no-one else in the Protectionist faction voted in favour of the bill. ${ }^{39}$ Lord George Bentinck, who did vote in favour, felt so isolated as a result that he resigned as leader of the Protectionists in the Commons a few days after the vote. ${ }^{40}$ The only known unequivocally supportive response to the speech was that of Isaac, who was reported by Sarah to have considered it 'the most important ever delivered in the House of Commons'. ${ }^{41}$

Benjamin's speech in December 1847 had been elicited in response to the refusal of Baron Lionel de Rothschild, who had been elected to the Commons earlier in the year, to take the Christian oath required of Members of Parliament. On 20 December a bill 'for the Relief of her Majesty's subjects professing the Jewish Religion' was introduced to the Commons by Lord John Russell, the Prime Minister, with a Second Reading of the bill fixed for 7 February 1848. Benjamin's letters reveal him to have been much preoccupied in late December and early January with the fallout from Bentinck's resignation which had been precipitated by his support for Jewish emancipation, but they also show him to have been energetically engaged

\footnotetext{
${ }^{37}$ Endelman, Broadening, p. 210-11.

${ }^{38}$ P. Smith, Disraeli: a brief life (Cambridge: Cambridge University Press, 1999), p.100.

${ }^{39}$ Parry, Benjamin Disraeli, p. 46.

${ }^{40}$ D. Cesarani, Disraeli: the novel politician (New Haven: Yale University Press, 2016), pp. 120-21.

${ }^{41}$ W.F. Monypenny and G.E. Buckle, The life of Benjamin Disraeli, Earl of Beaconsfield, new and rev. edn., 2 vols.

(London: John

Murrary, 1929), vol. 1, p. 886.
} 
in helping Rothschild to compose at speed a pamphlet outlining the 'Progress of Jewish Emancipation since 1929', to be published anonymously in an attempt to gain the support of members of parliament in both Houses. Benjamin had a meeting with Rothschild in the city on Tuesday December 21, the day after the bill had been introduced to the Commons. ${ }^{42}$ Five days later he was in his father's house in Bradenham for Christmas, ${ }^{43}$ but he continued to correspond with Rothschild about the pamphlet and to annotate the proofs until January $9 .{ }^{44}$ The pamphlet was eventually published with the date 15 January 1848 and received an enthusiastic review in the Jewish Chronicle on 25 February $1848 .{ }^{45}$ It is likely that the details of parliamentary proceeding recorded in the pamphlet were the work of Benjamin. In a letter to Rothschild on 3 January, he noted that he was sending 'in two packets, by this post, a sketch of the sort of thing you require'. ${ }^{46}$ Since the pamphlet was distributed anonymously, it is unsurprising that Benjamin's own name does not feature anywhere in the text. A long extract from the pamphlet covering "the last seven years" and including a passage as corrected by Benjamin in the proofs preserved in the Rothschild archives, is printed in the Sequel (866), preceded by a statement that 'the friends of civil and religious liberty will with pleasure reflect what has been gained for the Jews within the last few years'.

Benjamin had probably always intended to stay in Bradenham after Christmas until the end of the Aylesbury Quarter Sessions, which were held on 4-6 January, but it is likely that he wanted to return to London as soon as possible after 6 January in order to help to sort out the leadership crisis in his party. It was not to be. Isaac fell ill with flu on 7 January, and twelve days later he was dead. Benjamin did not leave Bradenham until 28 January.

If Isaac's enthusiasm for Jewish emancipation may have encouraged Benjamin to risk political isolation by throwing his weight behind the Jewish cause in December 1847, his death in January 1848 may have made it easier for Benjamin to lie low on the issue over the coming months and years. There may be some parallel with Isaac's own reluctance to resign formally from Bevis Marks Synagogue until after his own father's death in $1816{ }^{47}$ Benjamin does not seem to have been involved in the campaign of the Board of Deputies of British Jews, led by Montefiore and Goldsmid, which met frequently in Rothschild's offices between

\footnotetext{
42 Gunn and Wiebe, Benjamin Disraeli Letters, no. 1615.

${ }^{43}$ Gunn and Wiebe, Benjamin Disraeli Letters, no. 1617.

${ }^{44}$ Gunn and Wiebe, Benjamin Disraeli Letters, nos. 1617X, 1619X, 1619XA, 1619XB.

${ }^{45}$ Gunn and Wiebe, Benjamin Disraeli Letters, vol. 8, p. 422.

${ }^{46}$ Gunn and Wiebe, Benjamin Disraeli Letters, no. 1619X.

${ }^{47}$ Ogden, Isaac D'Israeli, pp. 199, 200.
} 
January and May 1848 to plan how to lobby for the Bill. ${ }^{48}$ When the Bill came to the Commons for its Second Reading in May, Benjamin kept silent, and he wrote to the Duke of Newcastle in February 1849 that he wished 'the Jew Bill', which had so much embarrassed him, was 'at the bottom of the Red Sea'. 49

When emancipation of the Jews in England was eventually achieved in 1858 this was not through the dedicated efforts of Benjamin to the cause. On the contrary, Benjamin set himself apart from Jews, claiming in a letter sent in February 1853 to his benefactor Sarah Brydges Willyams, a woman herself of Sephardi Jewish ancestry, that he 'was not bred among my race, and was nurtured in great prejudice against them' ${ }^{50}$ If Benjamin in his later political career ceased to harp on Jewish themes as he had in the first two decades of his life in politics, this may have been due not only to his having less time or need to write fiction but also to the absence of his father's influence on his life. ${ }^{51}$

It is quite touching to imagine Benjamin and Sarah in the house in Bradenham, surrounded by Isaac's great library, coming to terms with his sudden death and making rapid decisions about how to treat the literary legacy of a father of whom, by all accounts, they were both fond and proud. It is hard to know whether the specific decision to publish Isaac's history of the Jews in this anonymous form was prompted primarily by Benjamin's desire in this crisis in his political career to avoid being too directly associated with the arguments for Jewish emancipation, or by a concern that the text was not up to the standard which would do credit to Isaac's literary reputation, or by a wish to ensure that Isaac's desire to have his writings printed should be met even when the text was unlikely to appeal to a standard publisher, or simply by a need to make money from what constituted a substantial body of work. It is quite likely that all these reasons combined.

Isaac's history found its way into the homes of thousands of families in the United States as well as Britain in the magnificent 1876 edition, which included numerous illustrations of the Sequel as well as of the works of Josephus. But the main significance of the Sequel lies less in its influence on its readers (not least because we do not know how many of those who kept the beautifully bound volume on their shelves actually read beyond

\footnotetext{
48 A. Gilman, The emancipation of the Jews in England, 1830-1860 (New York: Garland, 1982), pp. 98-99.

49 Smith, Disraeli, p. 100.

${ }^{50}$ Endelman, Broadening, p.204.

${ }^{51}$ Endelman, Broadening, p. 220, on his move away from fiction writing as a factor.
} 
the text of Josephus to the history which followed) than in the intriguing story of its composition, and what it reveals both about the process of writing as a joint family endeavour in which Sarah Disraeli played a leading part and about the complex relation of Benjamin Disraeli to his Jewish origins at a crucial moment in his political career. 